\title{
T Follicular Helper Cells As a New Target for Immunosuppressive Therapies
}

\author{
Lin Yan ${ }^{1,2 * t}$, Kitty de Leur ${ }^{2,3 * t, ~ R u d i ~ W . ~ H e n d r i k s ~}{ }^{4}$, Luc J. W. van der Laan ${ }^{3}$, Yunying Shi ${ }^{5}$, \\ Lanlan Wang ${ }^{1}$ and Carla C. Baan ${ }^{2}$ \\ 'Department of Laboratory Medicine, West China Hospital, Sichuan University, Chengdu, China, ${ }^{2}$ Department of Internal \\ Medicine, Division of Nephrology and Transplantation, Erasmus MC, University Medical Center, Rotterdam, Netherlands, \\ ${ }^{3}$ Department of Surgery, Erasmus MC, University Medical Center, Rotterdam, Netherlands, ${ }^{4}$ Department of Pulmonary \\ Medicine, Erasmus MC, University Medical Center, Rotterdam, Netherlands, ${ }^{5}$ Department of Nephrology, West China \\ Hospital, Sichuan University, Chengdu, China
}

Over the past decade, antibody-mediated (humoral) rejection has been recognized as a common cause of graft dysfunction after organ transplantation and an important determinant for graft loss. In humoral alloimmunity, $T$ follicular helper (Tfh) cells play a crucial role, because they help naïve B cells to differentiate into memory B cells and alloantibodyproducing plasma cells within germinal centers. In this way, they contribute to the induction of donor-specific antibodies, which are responsible for the humoral immune response to the allograft. In this article, we provide an overview of the current knowledge on the effects of immunosuppressive therapies on Tfh cell development and function, and discuss possible new approaches to influence the activity of Tfh cells. In addition, we discuss the potential use of Tfh cells as a pharmacodynamic biomarker to improve alloimmune-risk stratification and tailoring of immunosuppression to individualize therapy after transplantation.

Keywords: $\mathbf{T}$ follicular helper cells, immunosuppression, humoral immunity, transplantation, allograft rejection, donor-specific antibodies, costimulation, cytokines

\section{INTRODUCTION}

Organ transplantation is the treatment of choice for end-stage organ failure. Although current immunosuppressive regimens are effective in the short-term, long-term allograft survival rates are still suboptimal with rejection being the leading cause of graft loss (1). Allograft rejection can develop from either cellular or humoral immune responses against the allograft, or from "mixed rejection" involving both types of responses (2). In particular, humoral anti-donor reactivity via the formation of donor-specific antibodies (DSA) is associated with poor allograft outcomes (3-5). Formation of DSA relies on antigen-activated T follicular helper (Tfh) cells, which are located in the germinal centers (GC) where they provide help to antigen-activated B cells, which in turn respond by differentiating into immunoglobulin-producing plasma cells and high-affinity memory B cells $(6,7)$.

\footnotetext{
Abbreviations: AMR, antibody-mediated rejection; APC, antigen-presenting cell; Bcl-6, B cell lymphoma 6; BCR, B cell receptor; Blimp-1, B lymphocyte-induced maturation protein-1; BTK, Bruton's tyrosine kinase; CNI, calcineurin inhibitor; CTLA4, cytotoxic T-lymphocyte-associated protein 4; CXCL13, C-X-C chemokine ligand 13; CXCR5, C-X-C chemokine receptor 5; DC, dendritic cell; DZ, dark zone; DSA, donor-specific antibodies; GC, germinal center; GOF, gain of function; ICOS, inducible T cell costimulatory molecule; LEF-1, lymphoid enhancer binding factor 1; LOF, loss of function; LRBA, LPS-responsive beige-like anchor; LZ, light zone; MMF, mycophenolate mofetil; NFAT, nuclear factor in activated T cells; PD-1, programmed death 1; PID, primary immunodeficiency; SHM, somatic hypermutation; SLO, secondary lymphoid organs: STAT, signal transducer and activator of transcription; TCF-1, T cell factor 1; Tht cell, $\mathrm{T}$ follicular helper cell; Tfr, $\mathrm{T}$ follicular regulatory; TGF- $\beta$, transforming growth factor- $\beta$; TLR7, toll-like receptor 7; TLR9, toll-like receptor 9; Treg, regulatory T.
} 
B cell depleting therapies have been used to control the formation of DSA in transplant recipients (8) but are not generally used as maintenance treatment because of the risk of side effects. Based on their pivotal role in regulating humoral immunity it can be postulated that Tfh cells, rather than B cells, could be targeted to inhibit the development of antibody-mediated anti-donor reactivity. Currently, no Tfh-specific agents have been evaluated in phase II or III trials. Several animal studies and a small number of clinical studies in organ transplant recipients have demonstrated the importance of Th cells in the process of alloantibody production (9). The specific effects of immunosuppressive therapies on Tfh cell activity, however, are less established and now subject to many ongoing research efforts. In this article, we summarize current knowledge on the interplay between immunosuppressive drugs and the generation and function of Tfh cells, and consider new biological targets that might influence the proliferation, differentiation, and activity of Tfh cells.

\section{BIOLOGY OF Tfh CELLS}

\section{Differentiation of Tfh Cells}

Differentiation of a human naïve $\mathrm{CD}^{+} \mathrm{T}$ cell into a $\mathrm{Tfh}$ cell is a complex and dynamic process involving multiple stages (10).
A combination of signals determines whether the naïve $\mathrm{T}$ cell differentiates toward a Th1, Th2, Th17, or Tfh subset including the expression of specific transcription factors, signal transducer and activator of transcription (STAT) proteins, cytokines, and chemokine receptors that allow the $\mathrm{T}$ cell to migrate to the site of inflammation. When a naïve $\mathrm{T}$ cell expresses $\mathrm{C}-\mathrm{C}$ chemokine receptor 7 (CCR7), migration is promoted to T cellrich zones in secondary lymphoid organs (SLO) and tertiary lymphoid structures present in chronically inflamed organs. Protein activin A [a member of the transforming growth factor- $\beta$ (TGF- $\beta$ ) superfamily] is present locally after the T cell encounters an antigen-presenting dendritic cell (DC) and mediates downregulation of CCR7, followed by upregulation of C-X-C chemokine receptor 5 (CXCR5) (11). Expression of CXCR5 is essential for localization of the Tfh cells at the T-B border of B-cell-rich follicles, where Tfh cells interact with $\mathrm{B}$ cells that recognize antigen via their B-cell receptor (BCR) (Figure 1). Sequential antigen presentation by DCs and B cells is required for optimal differentiation of Tfh cells and the subsequent GC reaction (12). After cognate antigen recognition, Th cells migrate inside the B-cell follicles and develop into activated GC-Tfh cells, which orchestrate the development of high-affinity GC B cells. In addition to CXCR5, activated

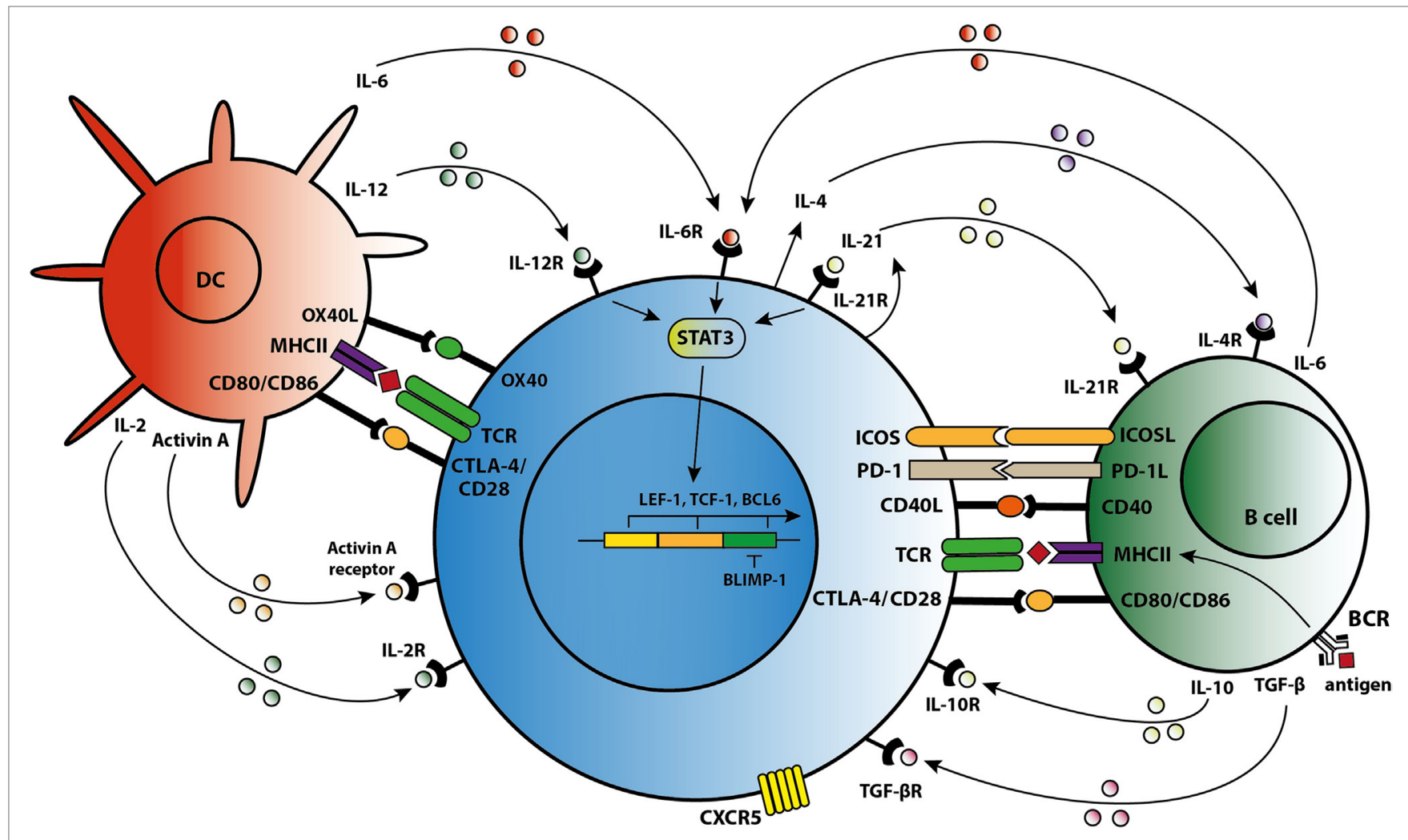

Tfh cell

FIGURE 1 | T follicular helper (Tfh) cell differentiation, activation, and crosstalk. Schematic overview of molecules involved in the differentiation of Tfh cells, the activation of Tfh cells by dendritic cells (DCs) and B cells, and the crosstalk of Tfh cells with DCs and B cells. 
Tfh cells express the coinhibitory protein programmed death 1 (PD-1) and inducible T-cell costimulatory molecule (ICOS) $(7,9)$. Recently, it has been demonstrated in a conditional knock out mouse model that Tfh cells express the transcription factors lymphoid enhancer binding factor 1 and $\mathrm{T}$ cell factor 1 , both of which are involved in regulation of the Tfh transcriptional repressor B cell lymphoma 6 (Bcl-6) (13). These transcription factors promote early Tfh cell differentiation by sustaining the expression of IL-6R $\alpha$ and gp130, and by promoting upregulation of ICOS and expression of Bcl-6 which is also known as the master transcription factor for Tfh cells and represses transcription of among others $B$ lymphocyte-induced maturation protein-1 (Blimp-1), T-box transcription factor (T-bet) (Th1 development), and RAR-related orphan receptor $\gamma t$ (ROR $\gamma t)$ (Th17 development) $(14,15)$. Apart from being present in SLOs, CXCR $5^{+} \mathrm{CD} 4^{+} \mathrm{Tfh}$ cells are also present in blood, representing approximately $10 \%$ of human circulating memory $\mathrm{CD} 4^{+} \mathrm{T}$ cells $(16,17)$. Memory Tfh cells form a heterogeneous population based on the expression of the chemokine receptors CXCR3 and CCR6: CXCR3-CCR6 ${ }^{-}$represent Tfh2 cells, CXCR3 ${ }^{+}{ }^{-} C{ }^{-} 6^{-}$ represent Tfh 1 cells, and CXCR $3^{-} \mathrm{CCR} 6^{+}$represent Tfh 17 cells (16). These subsets have distinct capacities to help B cells, the CXCR3- Tfh2 and Tfh17 cells promote B cell differentiation toward immunoglobulin-producing cells via secretion of IL-21, whereas CXCR3 ${ }^{+}$Tfh 1 cells lack this function $(18,19)$. In addition, the Tfh2 cells promote particularly IgG and IgE secretion, whereas Tfh17 cells are more efficient in promoting IgG and IgA secretion (16). Overall, an appropriate microenvironment is essential for coordination of Tfh cell lineage differentiation.

\section{Cytokines Involved in Tfh Cell Differentiation, Activation, and Function}

Coordinated activity by cytokines triggers specific transcription programs that stimulate the expression of molecules responsible for the effector function of Tfh cells (7). The differentiation of naïve human $\mathrm{CD}^{+} \mathrm{T}$ cells in the SLOs toward a Tfh cell phenotype is primarily mediated by IL-12, IL-6, and TGF- $\beta$ signaling. Activin A, in combination with IL-12, mediates an early shift toward the Tfh phenotype, including skewing toward expression of IL-21 $(11,20)$. IL-12 production is profoundly increased by activated DCs in the T cell-rich zone (21). TGF- $\beta$ is another cytokine involved in human Th cell differentiation that after binding to its receptor, phosphorylates the transcription factors STAT3 and STAT4, key steps in the Tfh cell differentiation process (22). As well as IL- 12 and TGF- $\beta$, IL- 6 contributes to differentiation into Tfh cells. One clinical study, for example, showed that secretion of IL- 6 by plasmablasts resulted in Tfh cell differentiation (23). Of note, interplay between IL-6 and IL-21 is required to achieve optimal Tfh cell differentiation and function, although an absence of either IL- 6 or IL-21 in a mouse model does not fully abolish Tfh cell formation $(24,25)$. By contrast, GC formation and the differentiation of B cells into immunoglobulin-producing plasmablasts are dependent on IL-21 producing Tfh cells $(25,26)$.

\section{Inhibition of Tfh Cells}

$\mathrm{T}$ follicular helper cell function depends on the balance between pro-inflammatory and anti-inflammatory signals. Several factors have been reported to control Tfh cell activation. Recently, it became evident that a subset of regulatory $\mathrm{T}$ (Treg) cells-the follicular regulatory $\mathrm{T}$ (Tfr) cells-express Foxp3, Bcl-6, and CXCR5 and have the capacity to regulate the Tfh-driven GC reaction (27-29). However, the immunoregulatory mechanisms by which Tfr cell functions are controlled are largely unknown. Animal studies have shown that the coinhibitory receptor cytotoxic T-lymphocyte-associated protein 4 (CTLA4) that is highly expressed by Tfr cells and moderately expressed on Tfh cells is involved in the suppressive effects of these cells. Tfr cells lacking the coinhibitory molecule CTLA4 have an impaired ability to inhibit B cell antibody production $(30,31)$. Conversely, mice deficient for PD-1 on Tfr cells have increased suppressive activity, since PD-1 controls the activation of Tfr cells (32). In kidney transplant patients who received anti-CD20 rituximab induction therapy, both Tfh and Tfr cells remained in the lymph nodes despite disruption of the GC and elimination of B cells (33), underlining their independent mechanism of action. The role of Tfr cells in preventing rejection of the allograft is largely unknown. Recently, Chen et al. showed that the ratio of Tfr cells in peripheral blood and renal graft biopsies from patients with antibody-mediated rejection (AMR) was significantly lower than in non-AMR patients, whereas Tfh2 and Tfh17 ratios increased, suggesting that increased Tfh activation levels contribute to AMR (34).

Anti-inflammatory cytokines secreted by Tfr cells also influence Tfr cell function. The pleiotropic cytokine IL-10 inhibits antibody production via regulation of the quantity and quality of Tfh cells in mice immunized with sheep red blood cells (35). By contrast, lymphocytic choriomeningitis virus (LCMV)-infected mice deficient for IL-10 had lower frequencies of virus-specific Tfh cells but no decrease in GC B cells or LCMV-specific antibodies (36). IL-2 is a critical factor for the regulation of Tfh-B cell interaction in vivo. Although originally recognized as an essential T-cell growth factor, IL-2 suppresses Tfh cell differentiation via activation of Blimp-1 resulting in a hampered formation of antigen-specific B cells and IgG responses in mice infected with the influenza virus $(37,38)$. Ray et al. recently demonstrated that IL-2-mediated activation of Akt kinase and mTORc1 was necessary to shift differentiation to Th1, with less differentiation to Tfh cells (39). By contrast, IL-21 inhibits the expression of CD25 (part of the IL-2 receptor) in a Bcl-6-dependent manner (40).

\section{Tfh-B Cell Crosstalk}

Cytokines and costimulatory molecules secreted by B cells are able to encourage activation of Tfh cells within the GC (Figure 1). Moreover, apart from their role as an antigenpresenting cell (APC), B cells contribute to the activation and regulation of the Tfh cells via secretion of cytokines like IL-6 and IL-10 (41, 42). Meanwhile, Tfh cells are involved in the GC reaction to promote $\mathrm{B}$-cell activation. The GC consists of a polarized structure with two compartments that are designed for proliferation and affinity selection. Within the dark zone (DZ), B cells undergo several rounds of proliferation and somatic hypermutation (SHM) in the V-region of their BCR (43). The point mutations that are created during SHM allow 
affinity maturation and lead to antibody diversity. Afterward, the DZ B cells migrates to the light zone (LZ), where they capture antigen presented by follicular DC networks and present it on MHC class II molecules to cognate Tfh cells (44). The amount of antigen captured by the B cell and presented to Tfh cells in the LZ directly corresponds to the amount of B-cell division and hypermutation in the DZ (45). Thus, T-cell help and not direct competition for antigen is the limiting factor in GC selection (46). High-affinity B cells present antigen to cognate Tfh cells, triggering a signaling pathway that allows (i) B-cell differentiation into long-living plasma cells, (ii) differentiation of long-lived memory B cells, or (iii) recirculation of B cells to the DZ for a new round of division and SHM (47). Activated Tfh cells produce IL-21 and IL-4, two cytokines that support B cell differentiation. Within the GC, Tfh cell function changes from IL-21+ Tfh cells, responsible for the selection of high-affinity B cell clones, toward IL- $4^{+}$Tfh cells that have high expression of CD40L and which direct B-cell class switch recombination and differentiation toward antibody-producing plasma cells $(48,49)$. PD- $1^{\text {hi }}$ Tfh cells are involved in this GC reaction while $\mathrm{PD}-1^{\text {lo }}$ Tfh cells represent precursor memory $\mathrm{T}$ cells with a Tfh-like phenotype (50). In a previous study, we found co-localization of $\mathrm{T}$ and $\mathrm{B}$ cells in cellular infiltrates of renal rejection biopsies, supporting a role for $\mathrm{T}-\mathrm{B}$ cell interaction within the kidney allograft (51).

\section{Genetic Defects Influencing Human Tfh Cell Differentiation}

Several heritable monogenic defects are known to affect the function and differentiation of Tfh cells. PBMCs of patients with primary immunodeficiencies (PIDs) have been characterized in various studies (52-57). In these studies, loss-of-function (LOF) mutations in the genes encoding STAT3, ICOS, Bruton's tyrosine kinase (BTK), CD40L, NF- $\mathrm{BB}$ essential modulator, and IL10R reduced the numbers of Tfh cells $(52,55,56)$. LOF mutations in the genes encoding STAT3, IL21-R, and gain-offunction (GOF) mutation in the gene encoding STAT1 resulted in a phenotype with elevated levels of IFN $\gamma$ and PD-1, both of which control Tfh-mediated B cell differentiation. By contrast, LOF mutations in IFNGR1/2, STAT1, and IL12RB1 genes caused impaired function of IFN $\gamma$ and thus promoted Tfh-B-cell interaction (52). Another study by Ma et al. reported that mutations in the genes encoding STAT3, IL-21R, CD40L, IFNGR1 LOF, or STAT1 GOF inhibit the differentiation of Tfh cells via impairing the generation of IL-21 (53). Lower frequencies of Tfh cells were observed in patients with two transmembrane activator and CAML interactor mutations compared with patients with a single mutation or without mutations (57). A study by Alroqi et al. described the presence of Tfh cells in patients with LPS-responsive beige-like anchor (LRBA) deficiencies. LRBA promotes the intracellular transport of CTLA4 toward the cell membrane, mostly expressed on Treg cells and Th17 cells (58). In all patients studied, increased frequencies of Th cells were measured associated with low CTLA4 expression levels on the Treg cells (54). When these patients were treated with CTLA4-Ig therapy, the frequencies of Tfh levels significantly decreased (54). To this end, Tfh-cell frequencies may be a useful readout in patients with LRBA and CTLA4 deficiencies to monitor the effect of CTLA4-Ig therapy. Taken together, the defects in differentiation of Tfh cells found in various PID patients provide strong evidence that the genes mutated in these diseases are essential for Tfh differentiation. Moreover, the finding of reduced Tfh cells in X-linked agammaglobulinemia patients with mutations in BTK shows that Tfh development is B cell dependent (52).

\section{THE EFFECTS OF CONVENTIONAL IMMUNOSUPPRESSION ON Tfh CELLS}

Maintenance immunosuppression after solid organ transplantation typically consists of a calcineurin inhibitor (CNI), either tacrolimus (Tac) or cyclosporin $\mathrm{A}$, the $\mathrm{T}$-cell proliferation inhibitor mycophenolate mofetil and steroids. An in vitro study analyzing the effect of methylprednisolone and CNI agents on $\mathrm{T}$ cells showed that these immunosuppressants could inhibit differentiation of human naïve $\mathrm{CD} 4^{+} \mathrm{T}$ cells into $\mathrm{Tfh}$ cells (59). In vivo, we found that Tfh-like cells are present in the circulation of kidney transplant recipients receiving Tac-based immunosuppression. These circulating Tfh-like cells have the capacity to induce B-cell differentiation into immunoglobulinproducing plasmablasts (51). A recent study from our group demonstrated that Tac had a small inhibitory effect on Tfh-cell generation in vitro and could partially prevent Tfh-cell activation. The production of IL-21 was incompletely inhibited by high concentrations of Tac, which may be why the remaining activated Tfh cells retained the potential capacity to assist B cells (60). In another study, methylprednisolone treatment of patients with systemic lupus erythematosus was found to reduce the number of peripheral $\mathrm{CD} 4^{+} \mathrm{CXCR} 5^{+} \mathrm{PD}-1^{+} \mathrm{T}$ cells, but without any evidence of altered Tfh function (61). Based on the available data, it can be concluded that conventional immunosuppressive therapies do not block Tfh-cell activity completely and Tfh-cell activity could usefully be examined in patients with allograft rejection or rapidly declining graft function.

This limited basis of evidence highlights that there is no clear understanding about the mechanisms by which immunosuppressants affect the development of Tfh cells. CNIs suppress IL-2 production through inhibiting the dephosphorylation of nuclear factor in activated T cells (NFAT), which is the key transcription factor for IL-2 and its receptor (Figure 2) (62). In a mouse model with acute viral infection, Ray et al. (39) demonstrated that IL-2 is able to enhance the expression of the transcriptional repressor Blimp-1 through the STAT5 and $\mathrm{PI} 3 \mathrm{~K}-\mathrm{Akt}$ signaling pathway and promotes inhibition of $\mathrm{Bcl}-6$ expression in activated $\mathrm{T}$ cells. It ultimately shifts the immune reaction during $\mathrm{T}$-cell differentiation away from a humoral response (Figure 2A). In theory, CNIs may influence Tfh differentiation through the control of IL-2 expression (Figure 2B). Basiliximab may also control Tfh differentiation in the same manner via blockade of the IL-2 receptor (Figure 2B). However, as proved in a mouse model, NFAT activity, which is suppressed by Tac, is also a functional requirement for Tfh differentiation and may induce secretion of IL-21 by Tfh cells $(63,64)$. Since 


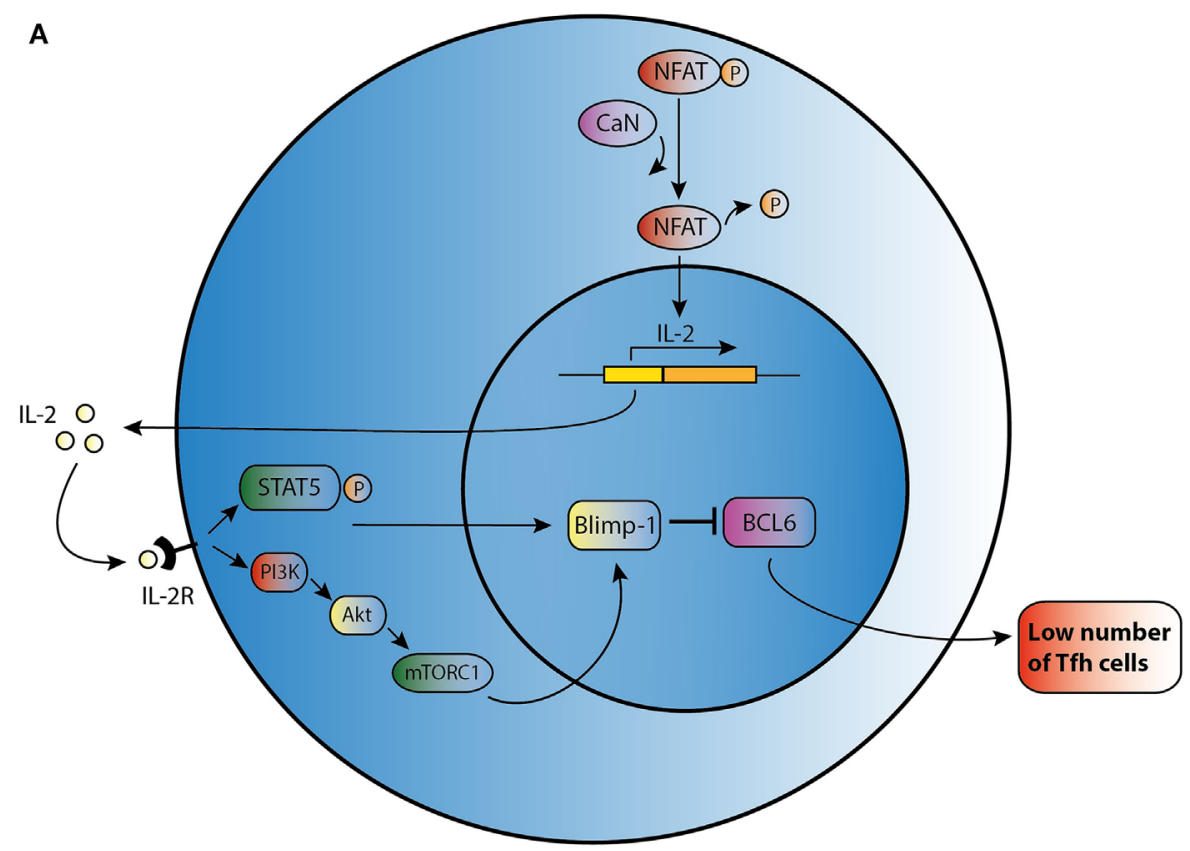

Activated T cell

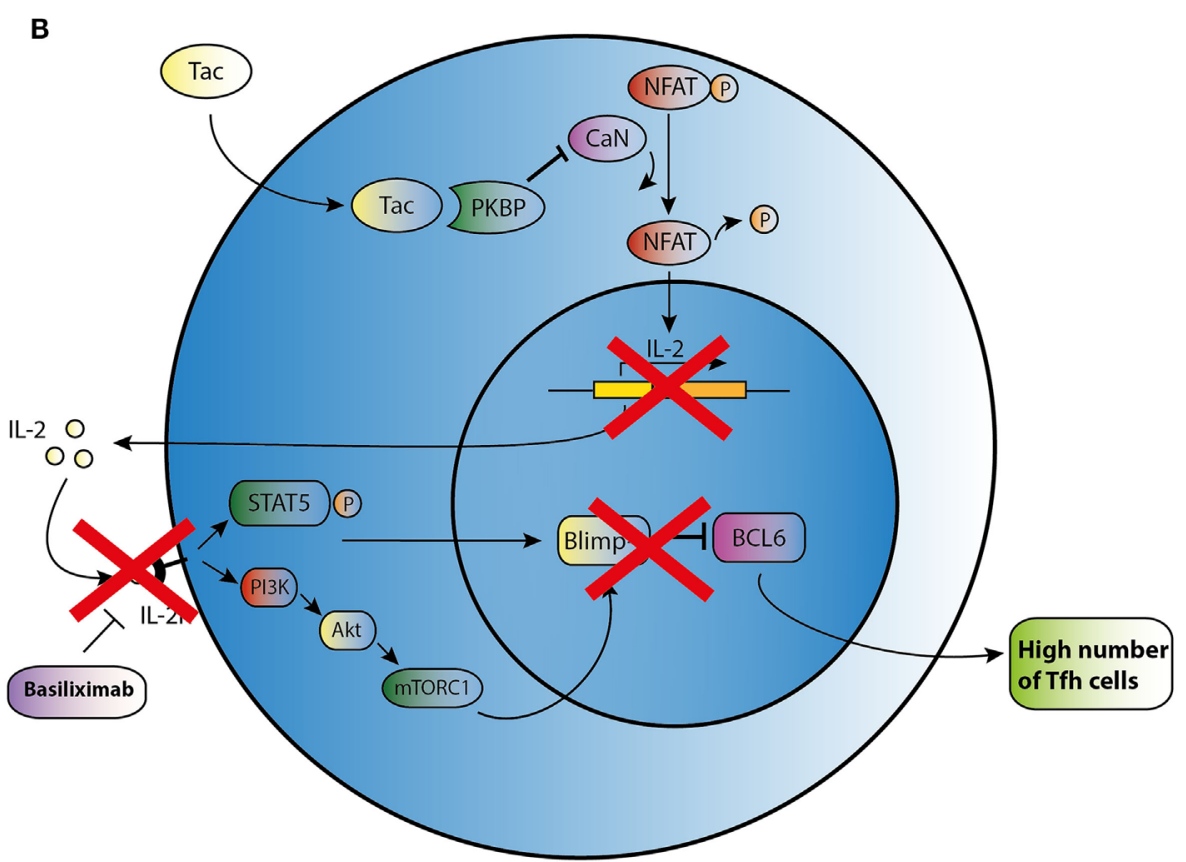

Activated T cell + tacrolimus/basiliximab

FIGURE 2 | Possible effect of tacrolimus (Tac) and basiliximab on T follicular helper (Tfh) cell differentiation and activation. (A) An activated T cell is depicted in the upper panel. (B) After addition of Tac, calcineurin (CaN) is blocked, and dephosphorylation of cytoplasmic nuclear factor in activated T cells (NFAT) is inhibited resulting in lower levels of IL-2 transcription. IL-2 promotes transcription of B lymphocyte-induced maturation protein-1 (Blimp-1), a co-repressor of B cell lymphoma 6 (Bcl-6). In the absence of IL-2, lower transcription of Blimp-1 leads to increased expression of BCL6 and thus may enhance Tfh cell numbers. Basiliximab may promote the same effect of enhancing Tfh cell numbers via blocking the IL-2R.

CNIs suppress NFAT activity and the corresponding expression of IL-2 and most likely also of IL-21, this class of agents may influence the generation of Tfh cells through regulating the balance of IL-2 and IL-21. However, further studies are needed to determine the mode of action of immunosuppressive agents on Tfh cells. 


\section{Tfh-TARGETED IMMUNOTHERAPY}

\section{Coinhibitory Pathways}

As summarized in Figure 3, different strategies can be employed to target Tfh activation and/or function. CTLA4 could control B cell responses by modulating Tfh-cell activity (30). Abatacept and belatacept are first and second generations of the fusion protein CTLA4-Ig. A study based on a mouse skin graft model by Kim et al. showed that abatacept reduced the number of activated $\mathrm{CD} 4{ }^{+} \mathrm{PD}-1^{+} \mathrm{CXCR} 5^{+}$Tfh cells in the spleen, which was associated with suppression of antibodies directed against the skin transplant (65). CTLA4-Ig also inhibited the increase in circulating Tfh cells and B cell-mediated antibody production in a mouse heart transplant model (66). In primary Sjögren's syndrome patients, abatacept treatment attenuated circulating Tfh-cell numbers and Tfh-cell-dependent B cell hyperactivity (67). In kidney transplant patients, we found that belatacept partially inhibited Tfh-cell activation; the remaining activated Tfh cells were able to provide B cell help. Belatacept is less potent in vitro than Tac in inhibiting Tfh-cell-dependent plasmablast formation (60). Based on these preliminary data, it seems that human circulating Tfh cells after transplantation are less susceptible to costimulation blockade than mouse Th cells. However, proof that lower susceptibility in humans leads to more extensive antibody-mediated anti-donor responses has not been established. New immune monitoring trials are needed to confirm the immunosuppressive effects of belatacept on human Tfh cells.

\section{Costimulatory Pathways}

$\mathrm{T}$ follicular helper cells control the quality of long-lived humoral immunity through the ICOS/ICOSL signaling pathway (68). ICOS is able to directly promote Tfh-cell recruitment toward the GC and acts as a linker between T and B cells, supporting positive selection for high-affinity bone-marrow plasma cells $(68,69)$. Based on these studies, targeting the ICOS/ICOSL signaling pathway might offer new opportunities to prevent production of DSA and to treat transplant patients with de novo DSA. A glyco-engineered antibody that depletes ICOS resulted in a significant reduction in anti-nucleosomal autoantibodies in an SLE lupus-prone mouse model (70). Sato et al. demonstrated that ICOS expression was upregulated on $\mathrm{T}$ cells in a canine hematopoietic cell transplantation model of graft rejection or chronic graft-versus-host disease. In this study, immunosuppressive effects were observed in mixed leukocyte reactions where anti-ICOS was combined with suboptimal concentrations of CLTA4-Ig or cyclosporine (71). Recently, another study showed that anti-ICOSL antibody did not impact the early Tfh differentiation in a mouse model with Plasmodium chabaudi AS infection, but ICOS is necessary for maintenance of a sustained high-affinity, protective Ab response (72). Targeting the ICOS pathway with biologicals is a promising new direction to control the function of Tfh cells and subsequently B cells. However, it is clear that more knowledge is warranted to better understand the reported discrepancies in above described in vitro and in vivo models. Therefore, the clinical use of anti-ICOS therapy is still in development.

The CD40L/CD40 signaling pathway is also important in the interaction between Tfh and B cells. There are several known anti-CD40 agents. One of these, 2C10R4, is currently being investigated in clinical trials. Kim et al. demonstrated in a rhesus macaques kidney transplant model that 2C10R4 prevented AMR via affecting Tfh cells and IL-21 production in GCs and reducing production of early de novo DSA (73). In this study, belatacept was as effective as $2 \mathrm{C} 10 \mathrm{R} 4$ in regulating Tfh cells and preventing acute rejection. More proof that blockade of the CD40-CD40L pathway is effective in inhibiting antibody production comes

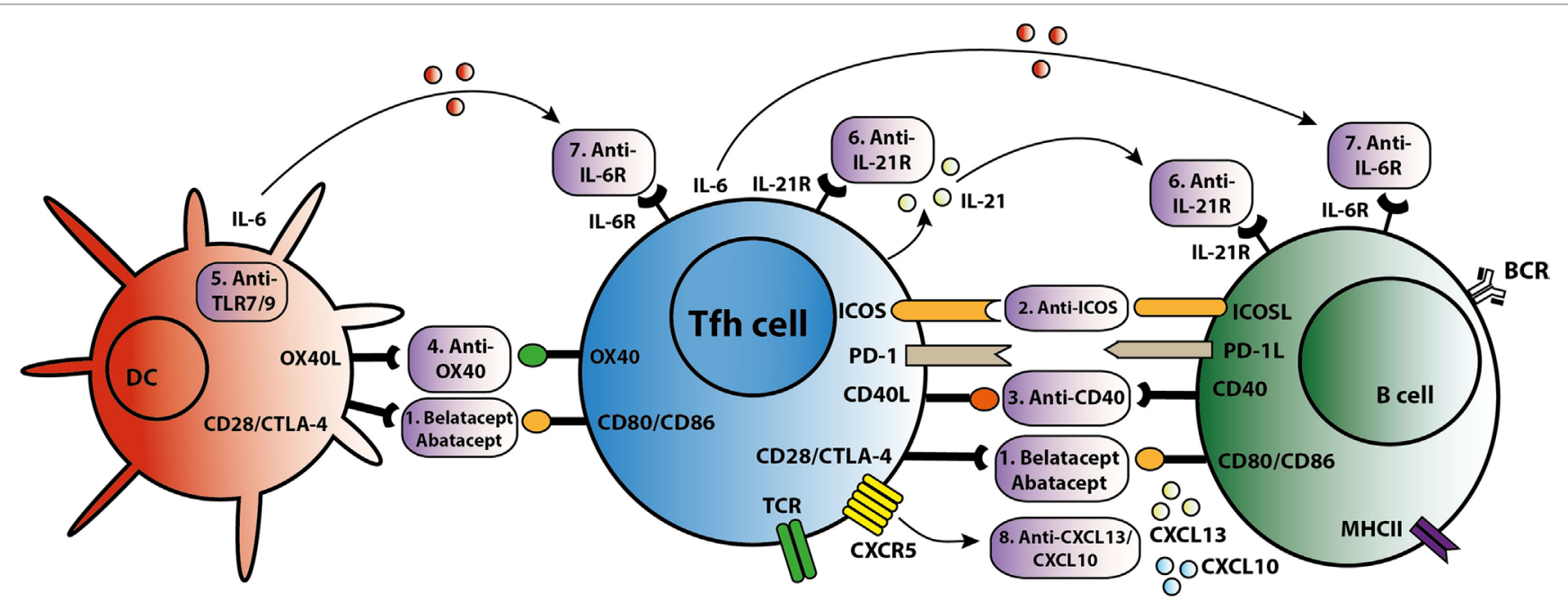

FIGURE 3 | T follicular helper (Tfh)-targeted immunotherapy. Blockage of the Tfh activation and function is established via several routes. An overview of these Tfh-targeted immunotherapies is summarized in this figure with (1) belatacept/abatacept, blocking costimulation of CD28/cytotoxic T-lymphocyte-associated protein 4 (CTLA4) and CD80/CD86, (2) anti-inducible T cell costimulatory molecule (ICOS), (3) anti-CD40, (4) anti-OX40, (5) anti toll-like receptor 7 (TLR7) or toll-like receptor 9 (TLR9), (6) anti-IL-21R, (7) anti-IL-6R, and (8) anti-C-X-C chemokine ligand 13 (CXCL13) and anti-CXCL10. 
from studies analyzing the effect of CFZ533, an Fc-silencing and non-B cell depleting anti-CD40 monoclonal antibody. Nonhuman primates treated with this agent had prolonged kidney allograft survival rates and better kidney function parameters than the untreated control group. Treatment with CFZ533 prevented the production of alloantibodies in these animals (74). Hence, next to CTLA4-Ig, anti-CD40 agents represent a promising option for costimulatory blockade to inhibit both Tfh and B cells. An alternative strategy is the combined use of Tac and new costimulatory blockers to inhibit allograft humoral immunity (73). However, the risk of over-immunosuppression should be considered.

The tumor necrosis factor receptor OX40, activated by its cognate ligand OX40L, functions as a T-cell costimulatory molecule. OX40L is expressed on DCs and myeloid APCs, but not on B cells. CD8 $\alpha^{-}$DCs, known for their MHC class II presentation, are localized at the inter-follicular zone and play a pivotal role in the induction of antigen-specific Tfh cells by upregulating the expression of ICOSL and OX40L (75). The frequency of circulating OX40L-expressing myeloid APCs shows a positive correlation with disease activity and the frequency of $\mathrm{ICOS}^{+}$blood Tfh cells in SLE. This may result from the capacity of OX40 signals to stimulate naïve and memory $\mathrm{CD} 4^{+} \mathrm{T}$ cells to express multiple Th cell molecules. Therefore, OX40 signals are adequate to induce these $\mathrm{T}$ cells to become functional $\mathrm{B}$ cell helpers (76). Blocking the OX40/OX40L pathway resulted in prolonged allograft survival in cardiac and skin transplantation mouse models $(77,78)$. However, the optimal timing for OX40 blockade is unclear and there are still potential problems with use of OX40/OX40L therapy for posttransplant autoimmunity (79). In addition, OX40L expression on myeloid APCs can be induced by immune complexes containing RNA via toll-like receptor 7 (TLR7) activation (76). Toll-like receptor 9 (TLR9) signaling in DCs led to higher numbers of Tfh and GC B cells, and accelerated production of broad-affinity anti-hapten IgG (80). Hence, TLR7/TLR9 might also offer a potential route to prevent antigen presentation of APC to Tfh cells.

\section{Cytokine-Dependent Pathways}

IL-21 acts as the dominate cytokine within the GC and is a promising target to inhibit Tfh function. Treatment of SLE lupus-prone mice with an anti-IL-21 blocking antibody reduced titers of autoantibodies, delayed progression of glomerulonephritis and diminished renal-infiltrating Tfh and Th1 cells, whilst improving overall survival (81). In an allogeneic setting, we recently demonstrated through ex vivo experimentation that IL-21 produced by donor antigen-activated Tfh cells could simulate humoral immunity, while an IL-21 receptor antagonist $(\alpha I L-21 R)$ could inhibit B cell differentiation and decrease the proportion of plasmablasts and production of IgM and IgG2 (26). Moreover, IL-21 has been shown capable of overcoming Tfr cell-mediated suppression and inhibiting Tfr cells, thus skewing the ratio of Tfh to Tfr cells $(40,82)$. Since IL-21 is more specific to the interaction of GC-Tfh cells than other cytokines and molecules, there is an urgent need to identify the efficiency and safety of IL-21 inhibition or IL-21R blockade in the suppression of humoral immunity. Both IL-21 receptor antagonists and IL-21 blocking antibodies have the potential to modulate the Tfh-mediated immune response.

IL-6 is a cytokine that offers another attractive option for targeting humoral immunity (23). Specific targeting of IL-6 receptor by tocilizumab in patients with rheumatoid arthritis led to a significant reduction in the number of circulating Tfh cells and in IL-21 production by $\mathrm{CD}^{+} \mathrm{T}$ cells (23). In transplantation, anti-IL- 6 receptor treatment decreased the number of IL $21^{+} \mathrm{CD} 4^{+}$and $\mathrm{CD} 4{ }^{+} \mathrm{CXCR} 5^{+}$Tfh cells in the spleens of allosensitized mice, as well as suppressing antibody recall responses and DSA levels $(83,84)$. A first study in kidney transplant patients proved that targeting the IL-6/IL-6R in highly sensitized patients could be a safe and new alternative in addition to currently used plasmapheresis with low-dose intravenous immunoglobulin (85). Given the interplay between IL-6 and IL-21, the combined blockade IL- 6 and IL-21 might be a better option to inhibit the differentiation, expansion and function of Tfh cells at all stages.

Transforming growth factor- $\beta$ appears to have multiple roles in transplantation. It promotes Tfh-cell differentiation (22), while it prevents Tfh-cell accumulation, self-reactive B cell activation and autoantibody production in GCs (86). TGF- $\beta$ is also a vital fibrosis cytokine (87). A clear understanding of the effect of TGF$\beta$ blockade on the entire humoral response and allograft fibrosis is required, however, before any therapeutic application.

\section{Tfh Migration-Dependent Pathways}

Targeting chemokine receptors or ligands to prevent Tfh migration offers another possible route for intervention. C-X-C chemokine ligand 13 (CXCL13) is produced in abundance by follicular stromal cells within B cell follicles. Expression of CXCL13, the receptor for CXCR5, on B and Tfh cells is necessary for their migration to the center of follicles to establish GCs (88). In addition, circulating Tfh cells respond to CXCL13 and can move back to the SLO GC (9). Although CXCL13 acts locally, it can also be detected in plasma and its level is associated with the extent of immune activity (89). Patients with active chronic graftversus-host disease have a lower frequency of circulating Tfh cells but higher CXCL13 plasma levels, suggesting increased homing of Tfh cells to SLOs (90). Circulating Tfh cells are also able to migrate into allografts via other chemokines such as CXCL10, and take part in the formation of tertiary lymphoid organs (9), which have been found in kidney biopsies after rejection (51). Anti-CXCL10 has been used to treat rheumatoid arthritis and ulcerative colitis in phase II clinical trials $(91,92)$. Depletion of $B$ cells by rituximab has no effect on tertiary lymphoid organs in chronic allograft dysfunction (93). Therefore, targeting CXCL13 or CXCL10 to inhibit the homing and trafficking of Tfh cells might be a more efficient strategy than B cell depletion to prevent the accumulation of Tfh in SLOs and formation of tertiary lymphoid organs in the allograft.

\section{Immune-Enhancing Pathways}

Programmed death 1, which is highly expressed on activated GC-Tfh cells, plays an important role in Tfh cell differentiation and formation of GCs (50). In theory, anti-PD-1 could control Tfh cell activation. However, contradicting results are presented. In a 
PD-1-deficient mouse model, Kawamoto et al. found increased production of Tfh cells with altered phenotypes and dysregulation of GCs, eventually resulting in reduced antigen affinity of IgA (94). Good-Jacobson et al. demonstrated that there were less plasma cells, GCs, and Tfh cells in the absence of PD-1; however, the remaining plasma cells were of a higher affinity (95). Others have also observed expansion of Tfh cells and enhanced humoral responses by blocking the PD-1 pathway $(96,97)$. In general, and thus also in organ transplantation patients, blockade of the PD-1 pathway boosts the immune response. These agents are approved for the treatment of solid tumors (98). A recent case report showed that a kidney transplant recipient given anti-PD-1 treatment for metastatic cutaneous squamous cell carcinoma had an acute cell-mediated allograft rejection two months after starting anti-PD-1, indirectly suggesting a role for PD-1 in regulation of transplant-related immune responses (99). There is no direct evidence that PD-1 agonists or antagonists would benefit transplant patients. The current observations might make PD-1 an unrealistic and ineffective target for achieving allograft humoral immunity.

\section{Tfh CELLS AS A BIOMARKER IN PHARMACODYNAMICS}

$\mathrm{T}$ follicular helper cells may have a role in pharmacodynamic monitoring of immunosuppression, as a marker for the extent to which the antibody response is inhibited. Circulating Tfh cells could be the counterpart of GC-Tfh cells as they share functional properties with Tfh cells residing in SLOs (16). However, whether these circulating Tfh cells are formed in the circulation, or have left the GC after exposure to an antigen and reside as memory Tfh cells in the blood is unknown. He et al. demonstrated that the circulating $C C R 7^{\text {lo }} \mathrm{PD}-1^{\text {hi }}$ Tfh subset correlated with clinical indices in autoimmune diseases and suggested it might serve as a biomarker for pathogenic antibody responses in that setting (100). Bentebibel et al. found that the presence of ICOS ${ }^{+} \mathrm{CXCR}^{+}$ $\mathrm{CXCR}^{+} \mathrm{CD}^{+} \mathrm{T}$ cells correlated with influenza vaccination antibody responses (101). Several papers have demonstrated that production of the neutralizing HIV antibody is dependent on Tfh cells, which could be a predictive biomarker for vaccine response $(19,102-104)$. Chenouard et al. suggested that a lack of Tfh cells, as seen in kidney transplant patients with operational tolerance, may induce a pro-tolerogenic environment with reduced risk of developing de novo DSA (105).

Individualized therapy after transplantation based on pharmacodynamic monitoring is the direction of immunosuppressant development. DSA, the traditional biomarker for humoral immunity, may not be the most sensitive indicator of the immune response after transplantation. As the launching cells for plasmablasts and memory B cells, the frequency of donorspecific Tfh cells might also be a sensitive tool to identify patients at risk for developing a DSA mediated immune response. These donor-specific Tfh cells can be quantified by donor-specific IL-21 enzyme-linked immunospot assay. Perhaps serum IL-21 measured by enzyme linked immunosorbent assay could also be a good alternative for pharmacodynamic monitoring. Of note, CXCL13 has also been suggested as a plasma biomarker for GC activity (106). Dose adjustments and switching immunosuppressive therapies based on monitoring of donor-specific IL- $21^{+}$ Tfh numbers in combination with serum CXCL13 might be of benefit in alloimmune-risk stratification and for individualized therapy in transplantation.

\section{PERSPECTIVE AND FUTURE DIRECTIONS}

Graft failure in immunosuppressed patients is often a combination of mixed cellular and AMR. Current immunosuppression seems to have limited capacity to control the allograft loss in recipients with high risk of rejection. Targeting the Tfh cell during maintenance therapy has the potential to prevent mixed clinical rejection early in the activation cascade, due to its pivotal role in conjugating the interaction of $\mathrm{T}$ and $\mathrm{B}$ cells. Suppression of both GC-Tfh cell formation and Tfh-cell migration via two different agents-for example, by blocking IL-21 and CXCL13-probably provides more robust control of humoral immunity. In addition, treatment strategies for patients undergoing solid organ transplantation should be defined according to the individual's immune activity (e.g., number of circulating donor-specific IL-2 $1^{+} \mathrm{T}$ cells) and risk of rejection. Monitoring donor-specific Tfh and memory B cells to guide the implementation of immunosuppression would help to tailor therapy appropriately. It would be of high interest to develop tools to easily investigate the specificity of these Tfh cells. In addition, immunosuppressive agents such as mTOR inhibitors with known Treg generating effects might also beneficially contribute to the generation of antigen-specific Tfr cells in transplant patients (107). This recently described $\mathrm{T}$ cell population controlling $\mathrm{B}$ cell immune responses is of high interest to intervene in the humoral alloimmune response leading to improved graft survival in patients after organ transplantation (27).

Although many agents can influence Tfh cell development and function, only a few are likely to be suitable for clinical investigation. Successful immunosuppressive drug development has a lifecycle that includes the discovery of a target molecule, research into the mechanisms involved, animal experimentation, and validation in clinical trials. Clinical assessment requires comparison of the new drug versus current therapies and monitoring of adverse effects. Comparing the effects of new Tfh-targeting therapeutics against the conventional immunosuppressants used in transplantation, particularly in terms of Tfh-dependent humoral immune activity, would be of considerable interest.

\section{AUTHOR CONTRIBUTIONS}

LY and KL researched the literature, evaluated evidence, and wrote the manuscript. RH, LL, YS, LW, and CB evaluated evidence and edited the manuscript.

\section{FUNDING}

This work was supported by a grant from the Erasmus University Medical Center, awarded by the Erasmus MC Medical research advisory committee (Mrace) grant no. 343564. 


\section{REFERENCES}

1. Nankivell BJ, Kuypers DR. Diagnosis and prevention of chronic kidney allograft loss. Lancet (2011) 378(9800):1428-37. doi:10.1016/S0140-6736(11) 60699-5

2. Loupy A, Haas M, Solez K, Racusen L, Glotz D, Seron D, et al. The Banff 2015 kidney meeting report: current challenges in rejection classification and prospects for adopting molecular pathology. Am J Transplant (2017) 17(1):28-41. doi:10.1111/ajt.14107

3. Loupy A, Lefaucheur C, Vernerey D, Prugger C, Duong van Huyen JP, Mooney N, et al. Complement-binding anti-HLA antibodies and kidneyallograft survival. N Engl J Med (2013) 369(13):1215-26. doi:10.1056/ NEJMoa1302506

4. Gaston RS, Cecka JM, Kasiske BL, Fieberg AM, Leduc R, Cosio FC, et al. Evidence for antibody-mediated injury as a major determinant of late kidney allograft failure. Transplantation (2010) 90(1):68-74. doi:10.1097/ TP.0b013e3181e065de

5. Einecke G, Sis B, Reeve J, Mengel M, Campbell PM, Hidalgo LG, et al. Antibody-mediated microcirculation injury is the major cause of late kidney transplant failure. Am J Transplant (2009) 9(11):2520-31. doi:10.1111/j.16006143.2009.02799.x

6. Vinuesa CG, Linterman MA, Yu D, MacLennan IC. Follicular helper T cells. Annu Rev Immunol (2016) 34:335-68. doi:10.1146/annurev-immunol-041015055605

7. Crotty S. T follicular helper cell differentiation, function, and roles in disease. Immunity (2014) 41(4):529-42. doi:10.1016/j.immuni.2014.10.004

8. Inaba A, Clatworthy MR. Novel immunotherapeutic strategies to target alloantibody-producing B and plasma cells in transplantation. Curr Opin Organ Transplant (2016) 21(4):419-26. doi:10.1097/MOT.0000000000000338

9. Walters GD, Vinuesa CG. T follicular helper cells in transplantation. Transplantation (2016) 100(8):1650-5. doi:10.1097/TP.0000000000001217

10. Nakayamada S, Takahashi H, Kanno Y, O'Shea JJ. Helper T cell diversity and plasticity. Curr Opin Immunol (2012) 24(3):297-302. doi:10.1016/j. coi.2012.01.014

11. Locci M, Wu JE, Arumemi F, Mikulski Z, Dahlberg C, Miller AT, et al. Activin A programs the differentiation of human TFH cells. Nat Immunol (2016) 17(8):976-84. doi:10.1038/ni.3494

12. Barnett LG, Simkins HM, Barnett BE, Korn LL, Johnson AL, Wherry EJ, et al. B cell antigen presentation in the initiation of follicular helper $\mathrm{T}$ cell and germinal center differentiation. JImmunol (2014) 192(8):3607-17. doi:10.4049/jimmunol.1301284

13. Choi YS, Gullicksrud JA, Xing S, Zeng Z, Shan Q, Li F, et al. LEF-1 and TCF-1 orchestrate $\mathrm{T}(\mathrm{FH})$ differentiation by regulating differentiation circuits upstream of the transcriptional repressor Bcl6. Nat Immunol (2015) 16(9):980-90. doi:10.1038/ni.3226

14. Nurieva RI, Chung Y, Martinez GJ, Yang XO, Tanaka S, Matskevitch TD, et al. Bcl6 mediates the development of T follicular helper cells. Science (2009) 325(5943):1001-5. doi:10.1126/science.1176676

15. Yu D, Rao S, Tsai LM, Lee SK, He Y, Sutcliffe EL, et al. The transcriptional repressor Bcl-6 directs $\mathrm{T}$ follicular helper cell lineage commitment. Immunity (2009) 31(3):457-68. doi:10.1016/j.immuni.2009.07.002

16. Morita R, Schmitt N, Bentebibel SE, Ranganathan R, Bourdery L, Zurawski G, et al. Human blood CXCR5(+)CD4(+) T cells are counterparts of T follicular cells and contain specific subsets that differentially support antibody secretion. Immunity (2011) 34(1):108-21. doi:10.1016/j.immuni.2010.12.012

17. Schmitt N, Bentebibel SE, Ueno H. Phenotype and functions of memory Th cells in human blood. Trends Immunol (2014) 35(9):436-42. doi:10.1016/j. it.2014.06.002

18. Boswell KL, Paris R, Boritz E, Ambrozak D, Yamamoto T, Darko S, et al. Loss of circulating CD4 T cells with B cell helper function during chronic HIV infection. PLoS Pathog (2014) 10(1):e1003853. doi:10.1371/journal. ppat. 1003853

19. Locci M, Havenar-Daughton C, Landais E, Wu J, Kroenke MA, Arlehamn CL, et al. Human circulating PD-1+CXCR3-CXCR5+ memory Th cells are highly functional and correlate with broadly neutralizing HIV antibody responses. Immunity (2013) 39(4):758-69. doi:10.1016/j.immuni.2013.08.031

20. Ma CS, Suryani S, Avery DT, Chan A, Nanan R, Santner-Nanan B, et al. Early commitment of naive human $\mathrm{CD} 4(+) \mathrm{T}$ cells to the $\mathrm{T}$ follicular helper (T(FH)) cell lineage is induced by IL-12. Immunol Cell Biol (2009) 87(8):590-600. doi:10.1038/icb.2009.64

21. Schmitt N, Morita R, Bourdery L, Bentebibel SE, Zurawski SM, Banchereau J, et al. Human dendritic cells induce the differentiation of interleukin-21producing $\mathrm{T}$ follicular helper-like cells through interleukin-12. Immunity (2009) 31(1):158-69. doi:10.1016/j.immuni.2009.04.016

22. Schmitt N, Liu Y, Bentebibel SE, Munagala I, Bourdery L, Venuprasad K, et al. The cytokine TGF-beta co-opts signaling via STAT3-STAT4 to promote the differentiation of human TFH cells. Nat Immunol (2014) 15(9):856-65. doi:10.1038/ni.2947

23. Chavele KM, Merry E, Ehrenstein MR. Cutting edge: circulating plasmablasts induce the differentiation of human T follicular helper cells via IL-6 production. J Immunol (2015) 194(6):2482-5. doi:10.4049/jimmunol.1401190

24. Karnowski A, Chevrier S, Belz GT, Mount A, Emslie D, D'Costa K, et al. B and $\mathrm{T}$ cells collaborate in antiviral responses via IL-6, IL-21, and transcriptional activator and coactivator, Oct2 and OBF-1.J Exp Med (2012) 209(11):2049-64. doi:10.1084/jem.20111504

25. Eto D, Lao C, DiToro D, Barnett B, Escobar TC, Kageyama R, et al. IL-21 and IL- 6 are critical for different aspects of B cell immunity and redundantly induce optimal follicular helper CD4 T cell (Tfh) differentiation. PLoS One (2011) 6(3):e17739. doi:10.1371/journal.pone.0017739

26. de Leur K, Dor FJ, Dieterich M, van der Laan LJ, Hendriks RW, Baan CC. IL-21 receptor antagonist inhibits differentiation of B cells toward plasmablasts upon alloantigen stimulation. Front Immunol (2017) 8:306. doi:10.3389/ fimmu.2017.00306

27. Chung Y, Tanaka S, Chu F, Nurieva RI, Martinez GJ, Rawal S, et al. Follicular regulatory $\mathrm{T}$ cells expressing Foxp3 and Bcl-6 suppress germinal center reactions. Nat Med (2011) 17(8):983-8. doi:10.1038/nm.2426

28. Wollenberg I, Agua-Doce A, Hernandez A, Almeida C, Oliveira VG, Faro J, et al. Regulation of the germinal center reaction by Foxp3+ follicular regulatory T cells. J Immunol (2011) 187(9):4553-60. doi:10.4049/jimmunol.1101328

29. Linterman MA, Pierson W, Lee SK, Kallies A, Kawamoto S, Rayner TF, et al. Foxp3+follicular regulatory $\mathrm{T}$ cells control the germinal center response. Nat Med (2011) 17(8):975-82. doi:10.1038/nm.2425

30. Sage PT, Paterson AM, Lovitch SB, Sharpe AH. The coinhibitory receptor CTLA-4 controls B cell responses by modulating $\mathrm{T}$ follicular helper, $\mathrm{T}$ follicular regulatory, and T regulatory cells. Immunity (2014) 41(6):1026-39. doi:10.1016/j.immuni.2014.12.005

31. Wing JB, Ise W, Kurosaki T, Sakaguchi S. Regulatory T cells control antigenspecific expansion of Tfh cell number and humoral immune responses via the coreceptor CTLA-4. Immunity (2014) 41(6):1013-25. doi:10.1016/j.immuni. 2014.12.006

32. Sage PT, Francisco LM, Carman CV, Sharpe AH. The receptor PD-1 controls follicular regulatory T cells in the lymph nodes and blood. Nat Immunol (2013) 14(2):152-61. doi:10.1038/ni.2496

33. Wallin EF, Jolly EC, Suchanek O, Bradley JA, Espeli M, Jayne DR, et al. Human T-follicular helper and T-follicular regulatory cell maintenance is independent of germinal centers. Blood (2014) 124(17):2666-74. doi:10.1182/ blood-2014-07-585976

34. Chen W, Bai J, Huang H, Bi L, Kong X, Gao Y, et al. Low proportion of follicular regulatory $\mathrm{T}$ cell in renal transplant patients with chronic antibody-mediated rejection. Sci Rep (2017) 7(1):1322. doi:10.1038/s41598-017-01625-3

35. Cai G, Nie X, Zhang W, Wu B, Lin J, Wang H, et al. A regulatory role for IL-10 receptor signaling in development and B cell help of T follicular helper cells in mice. J Immunol (2012) 189(3):1294-302. doi:10.4049/jimmunol.1102948

36. Tian Y, Mollo SB, Harrington LE, Zajac AJ. IL-10 regulates memory T cell development and the balance between Th1 and follicular Th cell responses during an acute viral infection. J Immunol (2016) 197(4):1308-21. doi:10.4049/ jimmunol.1502481

37. Leon B, Bradley JE, Lund FE, Randall TD, Ballesteros-Tato A. FoxP3+ regulatory $\mathrm{T}$ cells promote influenza-specific Th responses by controlling IL-2 availability. Nat Commun (2014) 5:3495. doi:10.1038/ncomms4495

38. Ballesteros-Tato A, Leon B, Graf BA, Moquin A, Adams PS, Lund FE, et al. Interleukin-2 inhibits germinal center formation by limiting $\mathrm{T}$ follicular helper cell differentiation. Immunity (2012) 36(5):847-56. doi:10.1016/j. immuni.2012.02.012

39. Ray JP, Staron MM, Shyer JA, Ho PC, Marshall HD, Gray SM, et al. The interleukin-2-mTORcl kinase axis defines the signaling, differentiation, and 
metabolism of T helper 1 and follicular B helper T cells. Immunity (2015) 43(4):690-702. doi:10.1016/j.immuni.2015.08.017

40. Jandl C, Liu SM, Canete PF, Warren J, Hughes WE, Vogelzang A, et al. IL-21 restricts $\mathrm{T}$ follicular regulatory $\mathrm{T}$ cell proliferation through $\mathrm{Bcl}-6$ mediated inhibition of responsiveness to IL-2. Nat Commun (2017) 8:14647. doi:10.1038/ncomms14647

41. Lund FE, Randall TD. Effector and regulatory B cells: modulators of CD4+ T cell immunity. Nat Rev Immunol (2010) 10(4):236-47. doi:10.1038/ nri2729

42. Corneth OB, de Bruijn MJ, Rip J, Asmawidjaja PS, Kil LP, Hendriks RW. Enhanced expression of Bruton's tyrosine kinase in B cells drives systemic autoimmunity by disrupting T cell homeostasis. J Immunol (2016) 197(1): 58-67. doi:10.4049/jimmunol.1600208

43. De Silva NS, Klein U. Dynamics of B cells in germinal centres. Nat Rev Immunol (2015) 15(3):137-48. doi:10.1038/nri3804

44. Victora GD, Nussenzweig MC. Germinal centers. Annu Rev Immunol (2012) 30:429-57. doi:10.1146/annurev-immunol-020711-075032

45. Gitlin AD, Shulman Z, Nussenzweig MC. Clonal selection in the germinal centre by regulated proliferation and hypermutation. Nature (2014) 509(7502):637-40. doi:10.1038/nature13300

46. Victora GD, Schwickert TA, Fooksman DR, Kamphorst AO, Meyer-Hermann M, Dustin ML, et al. Germinal center dynamics revealed by multiphoton microscopy with a photoactivatable fluorescent reporter. Cell (2010) 143(4):592-605. doi:10.1016/j.cell.2010.10.032

47. Kwun J, Manook M, Page E, Burghuber C, Hong J, Knechtle SJ. Crosstalk between $\mathrm{T}$ and $\mathrm{B}$ cells in the germinal center after transplantation. Transplantation (2017) 101(4):704-12. doi:10.1097/TP.0000000000001588

48. Shulman Z, Gitlin AD, Weinstein JS, Lainez B, Esplugues E, Flavell RA, et al. Dynamic signaling by $\mathrm{T}$ follicular helper cells during germinal center $\mathrm{B}$ cell selection. Science (2014) 345(6200):1058-62. doi:10.1126/science.1257861

49. Weinstein JS, Herman EI, Lainez B, Licona-Limon P, Esplugues E, Flavell R, et al. TFH cells progressively differentiate to regulate the germinal center response. Nat Immunol (2016) 17(10):1197-205. doi:10.1038/ni.3554

50. Trub M, Barr TA, Morrison VL, Brown S, Caserta S, Rixon J, et al. Heterogeneity of phenotype and function reflects the multistage development of $\mathrm{T}$ follicular helper cells. Front Immunol (2017) 8:489. doi:10.3389/fimmu.2017.00489

51. de Graav GN, Dieterich M, Hesselink DA, Boer K, Clahsen-van Groningen MC, Kraaijeveld R, et al. Follicular $\mathrm{T}$ helper cells and humoral reactivity in kidney transplant patients. Clin Exp Immunol (2015) 180(2):329-40. doi:10.1111/ cei. 12576

52. Ma CS, Wong N, Rao G, Avery DT, Torpy J, Hambridge T, et al. Monogenic mutations differentially affect the quantity and quality of $\mathrm{T}$ follicular helper cells in patients with human primary immunodeficiencies. JAllergy Clin Immunol (2015) 136(4):993-1006.e1. doi:10.1016/j.jaci.2015.05.036

53. Ma CS, Wong N, Rao G, Nguyen A, Avery DT, Payne K, et al. Unique and shared signaling pathways cooperate to regulate the differentiation of human CD4+ T cells into distinct effector subsets. J Exp Med (2016) 213(8):1589-608. doi:10.1084/jem.20151467

54. Alroqi FJ, Charbonnier LM, Baris S, Kiykim A, Chou J, Platt CD, et al. Exaggerated follicular helper T-cell responses in patients with LRBA deficiency caused by failure of CTLA4-mediated regulation. JAllergy Clin Immunol (2017). doi:10.1016/j.jaci.2017.05.022

55. Martini H, Enright V, Perro M, Workman S, Birmelin J, Giorda E, et al. Importance of $\mathrm{B}$ cell co-stimulation in $\mathrm{CD} 4(+) \mathrm{T}$ cell differentiation: X-linked agammaglobulinaemia, a human model. Clin Exp Immunol (2011) 164(3):381-7. doi:10.1111/j.1365-2249.2011.04377.x

56. Bossaller L, Burger J, Draeger R, Grimbacher B, Knoth R, Plebani A, et al. ICOS deficiency is associated with a severe reduction of CXCR5+CD4 germinal center Th cells. J Immunol (2006) 177(7):4927-32. doi:10.4049/ jimmunol.177.7.4927

57. Romberg N, Chamberlain N, Saadoun D, Gentile M, Kinnunen T, Ng YS, et al. CVID-associated TACI mutations affect autoreactive B cell selection and activation. J Clin Invest (2013) 123(10):4283-93. doi:10.1172/JCI69854

58. Broos CE, van Nimwegen M, In 't Veen JC, Hoogsteden HC, Hendriks RW, van den Blink B, et al. Decreased cytotoxic T-lymphocyte antigen 4 expression on regulatory T cells and Th17 cells in sarcoidosis: double trouble? Am J Respir Crit Care Med (2015) 192(6):763-5. doi:10.1164/rccm.201503-0635LE

59. De Bruyne R, Bogaert D, De Ruyck N, Lambrecht BN, Van Winckel M, Gevaert P, et al. Calcineurin inhibitors dampen humoral immunity by acting directly on naive B cells. Clin Exp Immunol (2015) 180(3):542-50. doi:10.1111/ cei. 12604

60. de Graav GN, Hesselink DA, Dieterich M, Kraaijeveld R, Verschoor W, Roelen DL, et al. Belatacept does not inhibit follicular T cell-dependent B-cell differentiation in kidney transplantation. Front Immunol (2017) 8:641. doi:10.3389/fimmu.2017.00641

61. Feng X, Wang D, Chen J, Lu L, Hua B, Li X, et al. Inhibition of aberrant circulating Tfh cell proportions by corticosteroids in patients with systemic lupus erythematosus. PLoS One (2012) 7(12):e51982. doi:10.1371/journal. pone. 0051982

62. Menon MC, Murphy B. Maintenance immunosuppression in renal transplantation. Curr Opin Pharmacol (2013) 13(4):662-71. doi:10.1016/j.coph. 2013.05.004

63. Martinez GJ, Hu JK, Pereira RM, Crampton JS, Togher S, Bild N, et al. Cutting edge: NFAT transcription factors promote the generation of follicular helper $\mathrm{T}$ cells in response to acute viral infection. J Immunol (2016) 196(5):2015-9. doi:10.4049/jimmunol.1501841

64. Kim HP, Korn LL, Gamero AM, Leonard WJ. Calcium-dependent activation of interleukin-21 gene expression in T cells. J Biol Chem (2005) 280(26):25291-7. doi:10.1074/jbc.M501459200

65. Kim I, Wu G, Chai NN, Klein AS, Jordan SC. Immunological characterization of de novo and recall alloantibody suppression by CTLA4Ig in a mouse model of allosensitization. Transpl Immunol (2016) 38:84-92. doi:10.1016/j. trim.2016.08.001

66. Oh B, Yoon J, Farris A III, Kirk A, Knechtle S, Kwun J. Rapamycin interferes with postdepletion regulatory $\mathrm{T}$ cell homeostasis and enhances DSA formation corrected by CTLA4-Ig. Am J Transplant (2016) 16(9):2612-23. doi:10.1111/ajt.13789

67. Verstappen GM, Meiners PM, Corneth OBJ, Visser A, Arends S, Abdulahad WH, et al. Attenuation of follicular helper T cell-dependent B cell hyperactivity by abatacept treatment in primary Sjogren's syndrome. Arthritis Rheum (2017) 69(9):1850-61. doi:10.1002/art.40165

68. Liu D, Xu H, Shih C, Wan Z, Ma X, Ma W, et al. T-B-cell entanglement and ICOSL-driven feed-forward regulation of germinal centre reaction. Nature (2015) 517(7533):214-8. doi:10.1038/nature13803

69. Xu H, Li X, Liu D, Li J, Zhang X, Chen X, et al. Follicular T-helper cell recruitment governed by bystander B cells and ICOS-driven motility. Nature (2013) 496(7446):523-7. doi:10.1038/nature12058

70. Mittereder N, Kuta E, Bhat G, Dacosta K, Cheng LI, Herbst R, et al. Loss of immune tolerance is controlled by ICOS in Sle1 mice. J Immunol (2016) 197(2):491-503. doi:10.4049/jimmunol.1502241

71. Sato M, Storb R, Loretz C, Stone D, Mielcarek M, Sale GE, et al. Inducible costimulator (ICOS) up-regulation on activated $\mathrm{T}$ cells in chronic graftversus-host disease after dog leukocyte antigen-nonidentical hematopoietic cell transplantation: a potential therapeutic target. Transplantation (2013) 96(1):34-41. doi:10.1097/TP.0b013e318295c025

72. Wikenheiser DJ, Ghosh D, Kennedy B, Stumhofer JS. The costimulatory molecule ICOS regulates host Th1 and follicular Th cell differentiation in response to Plasmodium chabaudi chabaudi AS infection. JImmunol (2016) 196(2):778-91. doi:10.4049/jimmunol.1403206

73. Kim EJ, Kwun J, Gibby AC, Hong JJ, Farris AB III, Iwakoshi NN, et al. Costimulation blockade alters germinal center responses and prevents antibody-mediated rejection. Am J Transplant (2014) 14(1):59-69. doi:10.1111/ ajt. 12526

74. Cordoba F, Wieczorek G, Audet M, Roth L, Schneider MA, Kunkler A, et al. A novel, blocking, Fc-silent anti-CD40 monoclonal antibody prolongs nonhuman primate renal allograft survival in the absence of $\mathrm{B}$ cell depletion. Am J Transplant (2015) 15(11):2825-36. doi:10.1111/ajt.13377

75. Shin C, Han JA, Koh H, Choi B, Cho Y, Jeong H, et al. CD8alpha(-) dendritic cells induce antigen-specific $\mathrm{T}$ follicular helper cells generating efficient humoral immune responses. Cell Rep (2015) 11(12):1929-40. doi:10.1016/j. celrep.2015.05.042

76. Jacquemin C, Schmitt N, Contin-Bordes C, Liu Y, Narayanan P, Seneschal J, et al. OX40 ligand contributes to human lupus pathogenesis by promoting $\mathrm{T}$ follicular helper response. Immunity (2015) 42(6):1159-70. doi:10.1016/j. immuni.2015.05.012

77. Kinnear G, Wood KJ, Marshall D, Jones ND. Anti-OX40 prevents effector T-cell accumulation and CD8+ T-cell mediated skin allograft rejection. Transplantation (2010) 90(12):1265-71. doi:10.1097/TP.0b013e3181fe5396 
78. Curry AJ, Chikwe J, Smith XG, Cai M, Schwarz H, Bradley JA, et al. OX40 (CD134) blockade inhibits the co-stimulatory cascade and promotes heart allograft survival. Transplantation (2004) 78(6):807-14. doi:10.1097/01. TP.0000131670.99000.54

79. Webb GJ, Hirschfield GM, Lane PJ. OX40, OX40L and autoimmunity: a comprehensive review. Clin Rev Allergy Immunol (2016) 50(3):312-32. doi:10.1007/s12016-015-8498-3

80. Rookhuizen DC, DeFranco AL. Toll-like receptor 9 signaling acts on multiple elements of the germinal center to enhance antibody responses. Proc Natl Acad Sci U S A (2014) 111(31):E3224-33. doi:10.1073/pnas.1323985111

81. Choi JY, Seth A, Kashgarian M, Terrillon S, Fung E, Huang L, et al. Disruption of pathogenic cellular networks by IL-21 blockade leads to disease amelioration in murine lupus. J Immunol (2017) 198(7):2578-88. doi:10.4049/ jimmunol.1601687

82. Sage PT, Ron-Harel N, Juneja VR, Sen DR, Maleri S, Sungnak W, et al. Suppression by TFR cells leads to durable and selective inhibition of B cell effector function. Nat Immunol (2016) 17(12):1436-46. doi:10.1038/ni.3578

83. Kim I, Wu G, Chai NN, Klein AS, Jordan S. Anti-interleukin 6 receptor antibodies attenuate antibody recall responses in a mouse model of allosensitization. Transplantation (2014) 98(12):1262-70. doi:10.1097/ TP.0000000000000437

84. Wu G, Chai N, Kim I, Klein AS, Jordan SC. Monoclonal anti-interleukin-6 receptor antibody attenuates donor-specific antibody responses in a mouse model of allosensitization. Transpl Immunol (2013) 28(2-3):138-43. doi:10.1016/j.trim.2013.03.003

85. Vo AA, Choi J, Kim I, Louie S, Cisneros K, Kahwaji J, et al. A phase I/II trial of the interleukin- 6 receptor-specific humanized monoclonal (tocilizumab) + intravenous immunoglobulin in difficult to desensitize patients. Transplantation (2015) 99(11):2356-63. doi:10.1097/TP.0000000000000741

86. McCarron MJ, Marie JC. TGF-beta prevents T follicular helper cell accumulation and B cell autoreactivity. J Clin Invest (2014) 124(10):4375-86. doi:10.1172/JCI76179

87. Meng XM, Nikolic-Paterson DJ, Lan HY. TGF-beta: the master regulator of fibrosis. Nat Rev Nephrol (2016) 12(6):325-38. doi:10.1038/nrneph.2016.48

88. Vincenti F, Rostaing L, Grinyo J, Rice K, Steinberg S, Gaite L, et al. Belatacept and long-term outcomes in kidney transplantation. N Engl J Med (2016) 374(4):333-43. doi:10.1056/NEJMoa1506027

89. Lee HT, Shiao YM, Wu TH, Chen WS, Hsu YH, Tsai SF, et al. Serum BLC/ CXCL13 concentrations and renal expression of CXCL13/CXCR5 in patients with systemic lupus erythematosus and lupus nephritis. J Rheumatol (2010) 37(1):45-52. doi:10.3899/jrheum.090450

90. Forcade E, Kim HT, Cutler C, Wang K, Alho AC, Nikiforow S, et al. Circulating $\mathrm{T}$ follicular helper cells with increased function during chronic graft-versus-host disease. Blood (2016) 127(20):2489-97. doi:10.1182/ blood-2015-12-688895

91. Mayer L, Sandborn WJ, Stepanov Y, Geboes K, Hardi R, Yellin M, et al. Anti-IP-10 antibody (BMS-936557) for ulcerative colitis: a phase II randomised study. Gut (2014) 63(3):442-50. doi:10.1136/gutjnl-2012-303424

92. Yellin M, Paliienko I, Balanescu A, Ter-Vartanian S, Tseluyko V, Xu LA, et al. A phase II, randomized, double-blind, placebo-controlled study evaluating the efficacy and safety of MDX-1100, a fully human anti-CXCL10 monoclonal antibody, in combination with methotrexate in patients with rheumatoid arthritis. Arthritis Rheum (2012) 64(6):1730-9. doi:10.1002/art.34330

93. Thaunat O, Patey N, Gautreau C, Lechaton S, Fremeaux-Bacchi V, DieuNosjean MC, et al. B cell survival in intragraft tertiary lymphoid organs after rituximab therapy. Transplantation (2008) 85(11):1648-53. doi:10.1097/ TP.0b013e3181735723

94. Kawamoto S, Tran TH, Maruya M, Suzuki K, Doi Y, Tsutsui Y, et al. The inhibitory receptor PD-1 regulates IgA selection and bacterial composition in the gut. Science (2012) 336(6080):485-9. doi:10.1126/science.1217718
95. Good-Jacobson KL, Szumilas CG, Chen L, Sharpe AH, Tomayko MM, Shlomchik MJ. PD-1 regulates germinal center B cell survival and the formation and affinity of long-lived plasma cells. Nat Immunol (2010) 11(6):535-42. doi:10.1038/ni.1877

96. Hams E, McCarron MJ, Amu S, Yagita H, Azuma M, Chen L, et al. Blockade of B7-H1 (programmed death ligand 1) enhances humoral immunity by positively regulating the generation of $\mathrm{T}$ follicular helper cells. J Immunol (2011) 186(10):5648-55. doi:10.4049/jimmunol.1003161

97. Velu V, Titanji K, Zhu B, Husain S, Pladevega A, Lai L, et al. Enhancing SIVspecific immunity in vivo by PD-1 blockade. Nature (2009) 458(7235):206-10. doi: $10.1038 /$ nature 07662

98. Queirolo P, Spagnolo F. Atypical responses in patients with advanced melanoma, lung cancer, renal-cell carcinoma and other solid tumors treated with anti-PD-1 drugs: a systematic review. Cancer Treat Rev (2017) 59:71-8. doi:10.1016/j.ctrv.2017.07.002

99. Lipson EJ, Bagnasco SM, Moore J Jr, Jang S, Patel MJ, Zachary AA, et al. Tumor regression and allograft rejection after administration of anti-PD-1. N Engl J Med (2016) 374(9):896-8. doi:10.1056/NEJMc1509268

100. He J, Tsai LM, Leong YA, Hu X, Ma CS, Chevalier N, et al. Circulating precursor CCR7(lo)PD-1(hi) CXCR5(+) CD4(+) T cells indicate Tfh cell activity and promote antibody responses upon antigen reexposure. Immunity (2013) 39(4):770-81. doi:10.1016/j.immuni.2013.09.007

101. Bentebibel SE, Lopez S, Obermoser G, Schmitt N, Mueller C, Harrod C, et al. Induction of ICOS+CXCR3+CXCR5+ TH cells correlates with antibody responses to influenza vaccination. Sci Transl Med (2013) 5(176):176ra32. doi:10.1126/scitranslmed.3005191

102. de Armas LR, Cotugno N, Pallikkuth S, Pan L, Rinaldi S, Sanchez MC, et al. Induction of IL21 in peripheral T follicular helper cells is an indicator of influenza vaccine response in a previously vaccinated HIV-infected pediatric cohort. J Immunol (2017) 198(5):1995-2005. doi:10.4049/jimmunol.1601425

103. Martin-Gayo E, Cronin J, Hickman T, Ouyang Z, Lindqvist M, Kolb KE, et al. Circulating CXCR5+CXCR3+PD-1lo Tfh-like cells in HIV-1 controllers with neutralizing antibody breadth. JCI Insight (2017) 2(2):e89574. doi:10.1172/jci.insight.89574

104. Gonzalez-Figueroa P, Roco JA, Vinuesa CG. Germinal center lymphocyte ratios and successful HIV vaccines. Trends Mol Med (2017) 23(2):95-7. doi:10.1016/j.molmed.2016.12.009

105. Chenouard A, Chesneau M, Bui Nguyen L, Le Bot S, Cadoux M, Dugast E, et al. Renal operational tolerance is associated with a defect of blood Tfh cells that exhibit impaired B cell help. Am J Transplant (2017) 17(6):1490-501. doi:10.1111/ajt.14142

106. Havenar-Daughton C, Lindqvist M, Heit A, Wu JE, Reiss SM, Kendric K, et al. CXCL13 is a plasma biomarker of germinal center activity. Proc Natl Acad Sci U S A (2016) 113(10):2702-7. doi:10.1073/pnas.1520112113

107. Gallon L, Traitanon O, Yu Y, Shi B, Leventhal JR, Miller J, et al. Differential effects of calcineurin and mammalian target of rapamycin inhibitors on alloreactive Th1, Th17, and regulatory T cells. Transplantation (2015) 99(9):1774-84. doi:10.1097/TP.0000000000000717

Conflict of Interest Statement: The authors declare that the research was conducted in the absence of any commercial or financial relationships that could be construed as a potential conflict of interest.

Copyright (c) 2017 Yan, de Leur, Hendriks, van der Laan, Shi, Wang and Baan. This is an open-access article distributed under the terms of the Creative Commons Attribution License (CC BY). The use, distribution or reproduction in other forums is permitted, provided the original author(s) or licensor are credited and that the original publication in this journal is cited, in accordance with accepted academic practice. No use, distribution or reproduction is permitted which does not comply with these terms. 